\title{
Cardiac condition during cooling and rewarming periods of therapeutic hypothermia after cardiopulmonary resuscitation
}

Serdar Demirgan, Kerem Erkalp*, M Salih Sevdi, Meltem Turkay Aydogmus, Numan Kutbay, Aydin Firincioglu, Ali Ozalp and Aysin Alagol

\begin{abstract}
Background: Hypothermia has been used in cardiac surgery for many years for neuroprotection. Mild hypothermia $(\mathrm{MH})$ [body temperature (BT) kept at $32-35^{\circ} \mathrm{C}$ ] has been shown to reduce both mortality and poor neurological outcome in patients after cardiopulmonary resuscitation (CPR). This study investigated whether patients who were expected to benefit neurologically from therapeutic hypothermia (TH) also had improved cardiac function.

Methods: The study included 30 patients who developed in-hospital cardiac arrest between September 17, 2012, and September 20, 2013, and had return of spontaneous circulation (ROSC) following successful CPR. Patient BTs were cooled to $33^{\circ} \mathrm{C}$ using intravascular heat change. Basal BT, systolic artery pressure (SAP), diastolic artery pressure (DAP), mean arterial pressure (MAP), heart rate, central venous pressure, cardiac output (CO), cardiac index (Cl), global end-diastolic volume index (GEDI), extravascular lung water index (ELWI), and systemic vascular resistance index (SVRI) were measured at $36^{\circ} \mathrm{C}, 35^{\circ} \mathrm{C}, 34^{\circ} \mathrm{C}$ and $33^{\circ} \mathrm{C}$ during cooling. $\mathrm{BT}$ was held at $33^{\circ} \mathrm{C}$ for 24 hours prior to rewarming. Rewarming was conducted $0.25^{\circ} \mathrm{C} / \mathrm{h}$. During rewarming, measurements were repeated at $33^{\circ} \mathrm{C}$, $34^{\circ} \mathrm{C}, 35^{\circ} \mathrm{C}$ and $36^{\circ} \mathrm{C}$. A final measurement was performed once patients spontaneously returned to basal BT. We compared cooling and rewarming cardiac measurements at the same BTs.

Results: SAP values during rewarming $\left(34^{\circ} \mathrm{C}, 35^{\circ} \mathrm{C}\right.$ and $\left.36^{\circ} \mathrm{C}\right)$ were lower than during cooling $(P<0.05)$. DAP values during rewarming (basal temperature, $34^{\circ} \mathrm{C}, 35^{\circ} \mathrm{C}$ and $36^{\circ} \mathrm{C}$ ) were lower than during cooling. MAP values during rewarming $\left(34^{\circ} \mathrm{C}, 35^{\circ} \mathrm{C}\right.$ and $\left.36^{\circ} \mathrm{C}\right)$ were lower than during cooling $(\mathrm{P}<0.05)$. $\mathrm{CO}$ and $\mathrm{Cl}$ values were higher during rewarming than during cooling. GEDI and ELWI did not differ during cooling and rewarming. SVRI values during rewarming $\left(34^{\circ} \mathrm{C}, 35^{\circ} \mathrm{C}, 36^{\circ} \mathrm{C}\right.$ and basal temperature) were lower than during cooling $(P<0.05)$.

Conclusions: To our knowledge, this is the first study comparing cardiac function at the same BTs during cooling and rewarming. In patients experiencing ROSC following CPR, TH may improve cardiac function and promote favorable neurological outcomes.
\end{abstract}

Keywords: Cardiac arrest, Therapeutic hypothermia, Cardiac function, Cardioprotection, Cardiac measurement

\footnotetext{
* Correspondence: keremerkalp@hotmail.com

Department of Anesthesiology and Reanimation, Bagcilar Educational and

Training Hospital, Şenlikköy Mah, İncir Sokak, No:1/3, Sarı Konaklar Sitesi,

B-Blok, Daire:6, Florya/ Bakırköy, Istanbul, Turkey
} 


\section{Background}

Hypothermia has been used in cardiac surgery for many years for neuroprotection [1,2]. Mild hypothermia (body temperature (BT) maintained at $32-35^{\circ} \mathrm{C}$ ) has been shown to reduce mortality and improve neurological status by $24-30 \%$ in patients who have undergone cardiopulmonary resuscitation (CPR) [3]. Although severe hypothermia $\left(\mathrm{BT}<31^{\circ} \mathrm{C}\right)$ damages cardiac function, mild hypothermia produces a cardioprotective effect $[4,5]$.

Post-cardiac arrest brain injury results from global brain ischemia during the reduction in general blood flow [6], and prolonged cardiovascular collapse negatively impacts neurologic outcome [7]. Therapeutic hypothermia (TH) is the process whereby $\mathrm{BT}$ is reduced to a target temperature of $32-34^{\circ} \mathrm{C}$ and maintained at this temperature for $24-48$ hours following cardiac arrest (CA) and return of spontaneous circulation (ROSC) [8-11]. The 2010 International Consensus on CPR and Emergency Cardiovascular Care Science treatment recommendations [12], the 2010 American Heart Association CPR guidelines [13], the 2010 Japan Resuscitation Council Guidelines [14], and the 2010 European Resuscitation Council (ERC) Guidelines [15] recommend $\mathrm{TH}$ following ROSC regardless of cardiac rhythm.

The aim of this study was to determine whether patients who were likely to benefit neurologically from TH would also experience favorable effects on cardiac function. Thus, we measured cardiac function during cooling and rewarming periods in patients receiving $\mathrm{TH}$ after CPR.

\section{Methods}

Patients were eligible if they developed CA in our hospital and acquired ROSC following successful CPR between September 17, 2012, and September 20, 2013 (Figure 1).

Patients were excluded if they: developed CA outside the hospital; were $<15$ years old; had late stage cancer; demonstrated severe cardiogenic shock; were pregnant; had cerebrovascular disease; demonstrated severe heart disease or pulmonary artery thromboembolism; or had aortic dissection or aneurysm.

Participants were admitted to the intensive care unit and received care consistent with 2010 ERC guidelines [15]. For internal BT measurements, a $16 \mathrm{~F}$ caliber, $44 \mathrm{~cm}$ heat probe silicone urinary catheter (Rusch ${ }^{\bullet}$ sensor series 400, Teleflex Medical IDA Business and Technology Park, Athlone, Ireland) was inserted. A $7 \mathrm{~F}$ three lumen central venous catheter (GE-CVC3720Y, GEMED, Istanbul, Turkey) was placed in the right subclavian vein. A $9.3 \mathrm{~F}$ caliber, five-lumen intravascular heat change catheter (IC-3893 AE, ICY Intravascular Heat Exchange Catheter Kit $^{\circ}$, ZOLL Circulation Inc., Sunnyvale, CA, USA) was placed into the right femoral vein. A $4 \mathrm{~F}$ caliber, $16 \mathrm{~cm}$ Philips Continuous Cardiac Output arterial thermodilution

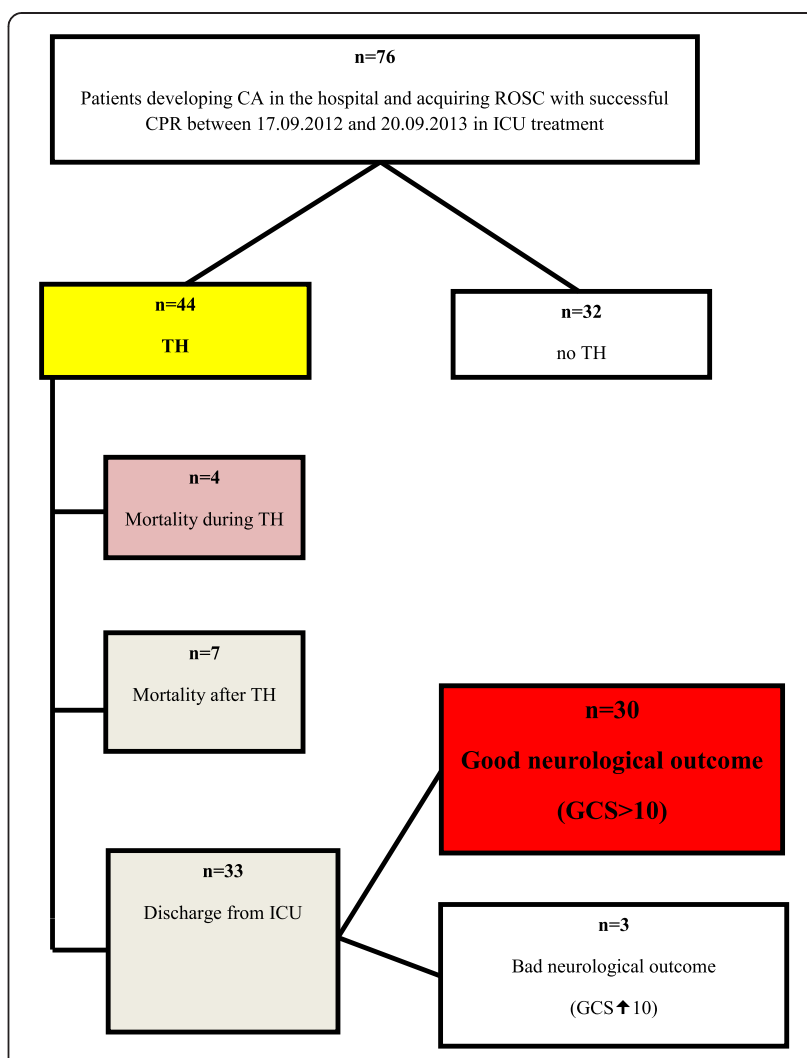

Figure 1 Flow diagram of the study.

catheter (PiCCO Plus ${ }^{\bullet}$, Pulsion Medical Systems AG, Munich, Germany) was placed in the right femoral artery and connected to the monitor.

Patients were sedated with midazolam $0.02 \mathrm{mg} / \mathrm{kg} / \mathrm{h}$ and remifentanil $60 \mu \mathrm{g} / \mathrm{kg} / \mathrm{h}$ intravenous infusions according to the Ramsay Sedation Scale level 3-4 [16]. Sedation was continued throughout $\mathrm{TH}$ and rewarming. During cooling, patients who demonstrated shaking that could adversely affect hemodynamic balance received 0.03-0.05 mg/ $\mathrm{kg}$ vecuronium intravenously. Consistent with hospital protocol, patients whose mean arterial pressure (MAP) was less than $60 \mathrm{mmHg}$ and unresponsive to a volume challenge received intravenous dopamine and noradrenalin infusion.

Patient BTs were cooled to $33^{\circ} \mathrm{C}$ using intravascular heat change at a rate of $0.5^{\circ} \mathrm{C} / \mathrm{h}$ (Thermogard $\mathrm{XP}^{\circ}$, Alsius Corp., Chelmsford, MA, USA). Basal BT, systolic artery pressure (SAP), diastolic artery pressure (DAP), MAP, heart rate (HR), central venous pressure (CVP), cardiac output $(\mathrm{CO})$, cardiac index $(\mathrm{CI})$, global end-diastolic volume index (GEDI), extravascular lung water index (ELWI) and systemic vascular resistance index (SVRI) values were measured at $36^{\circ} \mathrm{C}, 35^{\circ} \mathrm{C}, 34^{\circ} \mathrm{C}$ and $33^{\circ} \mathrm{C}$ during cooling. During the measurements, $15 \mathrm{~mL}$ of $0.9 \%$ saline solution at a temperature of less than $8^{\circ} \mathrm{C}$ was administered through a central venous catheter over 10 seconds or less. 
Measurements were obtained with the help of thermodilution curves using the $\mathrm{PiCCO}^{\circ}$ plus device. To ensure reliability, three injections and three series of measurements were performed for each temperature point, and mean values were used for analysis. Incompatible values among injections were deleted and the measurements were repeated. Central catheters were recessed during measurements. BT was held at $33^{\circ} \mathrm{C}$ for 24 hours prior to rewarming. Rewarming was conducted at $0.25^{\circ} \mathrm{C} / \mathrm{h}$. During rewarming, measurements were repeated at $33^{\circ} \mathrm{C}$, $34^{\circ} \mathrm{C}, 35^{\circ} \mathrm{C}$ and $36^{\circ} \mathrm{C}$. A final measurement was performed when patients spontaneously returned to basal BT.

We compared cooling and rewarming cardiac measurements conducted at the same BTs using means, standard deviations, ranges, medians, ratios and frequencies. Variable distribution was controlled using the Kolmogorov Smirnov test. Repeated measurements were analyzed with paired sample $t$-tests. SPSS 21.0 software (IBM ${ }^{\circ}$ Corp., Armonk, NY, USA) was used to analyze the data.

Permission to conduct this study was obtained from the Clinical Studies Local Ethics Committee of the Republic of Turkey Ministry of Health, Bagcilar Training and Research Hospital (17.09.2012-76). Written informed consent was obtained from the patients' first degree relatives.

\section{Results}

Patient demographic characteristics are presented in Table 1. Cardiac measurements during cooling and rewarming are shown in Table 2. SAP measurements during rewarming at $34^{\circ} \mathrm{C}$ and $35^{\circ} \mathrm{C}$ were lower than during rewarming at $33^{\circ} \mathrm{C}(\mathrm{P}<0.05)$. DAP values did not differ during cooling or rewarming. MAP values during rewarming at $34^{\circ} \mathrm{C}, 35^{\circ} \mathrm{C}$ and $36^{\circ} \mathrm{C}$ were lower than at $33^{\circ} \mathrm{C}(\mathrm{P}<0.05)$. HR values during cooling at $35^{\circ} \mathrm{C}, 34^{\circ} \mathrm{C}$ and $33^{\circ} \mathrm{C}$ were lower than at basal temperature $(\mathrm{P}<0.05)$. $\mathrm{HR}$ values during rewarming at $34^{\circ} \mathrm{C}, 35^{\circ} \mathrm{C}, 36^{\circ} \mathrm{C}$ and basal temperature were higher than at $33^{\circ} \mathrm{C}(\mathrm{P}<0.05)$. CVP values during rewarming at $35^{\circ} \mathrm{C}$ and $36^{\circ} \mathrm{C}$ were lower than at $33^{\circ} \mathrm{C}(\mathrm{P}<0.05)$. $\mathrm{CO}$ values during cooling at $35^{\circ} \mathrm{C}$ and $33^{\circ} \mathrm{C}$ were lower than at basal temperature $(\mathrm{P}<0.05)$. $\mathrm{CO}$ values during rewarming to basal temperature were higher than at $33^{\circ} \mathrm{C}(\mathrm{P}<0.05)$. CI values during cooling at $36^{\circ} \mathrm{C}, 35^{\circ} \mathrm{C}$ and $33^{\circ} \mathrm{C}$ were lower than at basal temperature $(\mathrm{P}<0.05)$. CI values during rewarming to basal temperature were higher than at $33^{\circ} \mathrm{C}(\mathrm{P}<0.05)$. GEDI values during cooling at $36^{\circ} \mathrm{C}$ were lower than at basal temperature. GEDI values at $33^{\circ} \mathrm{C}$ were higher than at basal temperature $(\mathrm{P}<0.05)$. GEDI values during rewarming at $35^{\circ} \mathrm{C}$ and basal temperature were higher than at $33^{\circ} \mathrm{C}$ $(\mathrm{P}<0.05)$. ELWI values during cooling at $36^{\circ} \mathrm{C}$ and $35^{\circ} \mathrm{C}$ were higher than at basal temperature $(\mathrm{P}<0.05)$. SVRI values during cooling at $35^{\circ} \mathrm{C}$ and $34^{\circ} \mathrm{C}$ were higher than at basal temperature $(\mathrm{P}<0.05)$. SVRI values during
Table 1 Summary of demographic and clinical characteristics of the $\mathbf{3 0}$ patients with cardiac arrest

\begin{tabular}{lc}
\hline Age in years (mean \pm SD) & $49.07 \pm 18.04$ \\
Males & $17(56.7 \%)$ \\
Height $(\mathrm{cm})$ & $171.4 \pm 6.9$ \\
Weight $(\mathrm{kg})$ & $86.3 \pm 17.6$ \\
Initial GCS level & \\
III & $23(76.7 \%)$ \\
IV & $5(16.7 \%)$ \\
V & $2(6.7 \%)$ \\
Cardiac arrest rhythm & \\
Ventricular tachycardia & $7(23.3 \%)$ \\
Ventricular fibrillation & $18(60 \%)$ \\
Asystole & $5(16.7 \%)$ \\
CPR duration (min) & $20 \pm 9.4$ \\
Coronary angiography & $9(30.0 \%)$ \\
& Yes \\
Time from ROSC to start of TH induction (min) & $46.86 \pm 14.73$ \\
SOFA Scores & $11.93 \pm 1.23$ \\
APACHE II Scores & $22.77 \pm 4.45$ \\
\hline
\end{tabular}

GCS: Glasgow Coma Scale.

CPR: Cardiopulmonary Resusication.

ROSC: Return of Spontaneous Circulation.

TH: Therapeutic Hypothermia.

SOFA: Sepsis-related Organ Failure Assessment.

APACHE: Acute Physiology and Chronic Health Evaluation.

rewarming at $34^{\circ} \mathrm{C}, 35^{\circ} \mathrm{C}, 36^{\circ} \mathrm{C}$ and at basal temperature were higher than at $33^{\circ} \mathrm{C}(\mathrm{P}<0.05)$.

Some cardiac function values differed when measured at the same temperature during cooling and rewarming phases. SAP values at $34^{\circ} \mathrm{C}, 35^{\circ} \mathrm{C}$ and $36^{\circ} \mathrm{C}$ were lower during rewarming compared with cooling $(\mathrm{P}<0.05)$. DAP values at basal temperature, $34^{\circ} \mathrm{C}, 35^{\circ} \mathrm{C}$ and $36^{\circ} \mathrm{C}$ were lower during rewarming than during cooling. MAP values at $34^{\circ} \mathrm{C}, 35^{\circ} \mathrm{C}$ and $36^{\circ} \mathrm{C}$ were lower during rewarming than during cooling $(\mathrm{P}<0.05)$. HR, CVP, GEDI and ELWI values at the same $\mathrm{BT}$ did not differ between cooling and rewarming periods. $\mathrm{CO}$ values were higher during rewarming than during cooling $(\mathrm{P}<0.05)$. CI values were higher during rewarming than during cooling $(\mathrm{P}<0.05)$. SVRI values at $34^{\circ} \mathrm{C}, 35^{\circ} \mathrm{C}, 36^{\circ} \mathrm{C}$ and basal temperature were lower during rewarming than during cooling $(\mathrm{P}<$ 0.05) (Table 2).

\section{Discussion}

In our comparison of cardiac function during the cooling and rewarming following CA and ROSC, we found that the greatest improvement occurred at $33^{\circ} \mathrm{C}$ at the beginning of the rewarming period and that improvement in cardiac function continued throughout the rewarming period. This was consistent with a recent study showing 
Table 2 Variation for the cardiac thermodilution maesurements at the same body temperature during cooling and rewarming periods

\begin{tabular}{|c|c|c|c|c|c|c|}
\hline \multicolumn{2}{|c|}{ Cooling (C)/Rewarming (RW) periods } & \multirow{2}{*}{$\frac{\text { Mean. } \pm \text { s.d. }}{10,7 \pm 33,8}$} & \multirow{2}{*}{$\frac{\mathbf{p}}{0,094}$} & \multirow[b]{2}{*}{ SVRI } & \multirow{2}{*}{$\begin{array}{c}\text { Mean. } \pm \text { s.d. } \\
792 \pm 672\end{array}$} & \multirow{2}{*}{$\frac{p}{0,000}$} \\
\hline BTbasal-C/BTbasal-RW & SAP & & & & & \\
\hline BT36-C/BT36-RW & & $12,9 \pm 29,5$ & 0,024 & & $1089 \pm 1791$ & 0,002 \\
\hline BT35-C/BT35-RW & & $14,8 \pm 29,1$ & 0,009 & & $1178 \pm 1444$ & 0,000 \\
\hline BT34-C/BT34-RW & & $11,9 \pm 29,9$ & 0,038 & & $777 \pm 1094$ & 0,001 \\
\hline BT33-C/BT33-RW & & $-6,7 \pm 30,7$ & 0,242 & & $72 \pm 1325$ & 0,768 \\
\hline BTbasal-C/BTbasal-RW & DAP & $8,2 \pm 19,7$ & 0,030 & $\mathrm{CO}$ & $-1,1 \pm 1,6$ & 0,001 \\
\hline BT36-C/BT36-RW & & $10,7 \pm 18,3$ & 0,003 & & $-0,8 \pm 1,6$ & 0,009 \\
\hline BT35-C/BT35-RW & & $11,0 \pm 19,6$ & 0,005 & & $-1,1 \pm 1,6$ & 0,000 \\
\hline BT34-C/BT34-RW & & $8,1 \pm 15,7$ & 0,008 & & $-0,8 \pm 1,4$ & 0,003 \\
\hline BT33-C/BT33-RW & & $2,2 \pm 19,2$ & 0,529 & & $-1,0 \pm 1,5$ & 0,002 \\
\hline BTbasal-C/BTbasal-RW & MAP & $6,7 \pm 24,4$ & 0,141 & $\mathrm{Cl}$ & $-0,6 \pm 1,0$ & 0,002 \\
\hline BT36-C/BT36-RW & & $11,8 \pm 19,9$ & 0,003 & & $-0,5 \pm 0,8$ & 0,001 \\
\hline BT35-C/BT35-RW & & $12,0 \pm 19,8$ & 0,002 & & $-0,7 \pm 0,9$ & 0,000 \\
\hline BT34-C/BT34-RW & & $9,1 \pm 19,7$ & 0,017 & & $-0,5 \pm 0,8$ & 0,002 \\
\hline BT33-C/BT33-RW & & $-2,3 \pm 24,2$ & 0,602 & & $-0,5 \pm 0,9$ & 0,012 \\
\hline BTbasal-C/BTbasal-RW & HR & $4,1 \pm 19,9$ & 0,273 & GEDI & $22,0 \pm 140,2$ & 0,397 \\
\hline BT36-C/BT36-RW & & $3,8 \pm 24,2$ & 0,397 & & $-72,3 \pm 167,1$ & 0,025 \\
\hline BT35-C/BT35-RW & & $-3,4 \pm 18,5$ & 0,326 & & $-83,8 \pm 285,3$ & 0,118 \\
\hline BT34-C/BT34-RW & & $-2,7 \pm 16,5$ & 0,384 & & $-18,6 \pm 171,8$ & 0,557 \\
\hline BT33-C/BT33-RW & & $2,7 \pm 19,5$ & 0,450 & & $-0,9 \pm 117,5$ & 0,966 \\
\hline BTbasal-C/BTbasal-RW & CVP & $0,8 \pm 7,2$ & 0,562 & ELWI & $0,1 \pm 2,9$ & 0,902 \\
\hline BT36-C/BT36-RW & & $1,8 \pm 5,4$ & 0,074 & & $1,3 \pm 4,1$ & 0,083 \\
\hline BT35-C/BT35-RW & & $1,8 \pm 5,3$ & 0,081 & & $1,0 \pm 3,8$ & 0,148 \\
\hline BT34-C/BT34-RW & & $1,9 \pm 5,6$ & 0,078 & & $0,6 \pm 3,6$ & 0,394 \\
\hline BT33-C/BT33-RW & & $1,7 \pm 5,6$ & 0,111 & & $0,7 \pm 2,8$ & 0,206 \\
\hline
\end{tabular}

Paired sample t test.

SAP measurements did not demonstrate any difference at Tbasal-C/Tbasal-RW and $33^{\circ} \mathrm{C}(\mathrm{p}>0.05)$. SAP values during rewarming at $34^{\circ} \mathrm{C}, 35^{\circ} \mathrm{C}, 36^{\circ} \mathrm{C}$ were lower as compared to measurements in cooling period $(\mathrm{p}<0.05)$. DAP measurements did not demonstrate any difference at $33^{\circ} \mathrm{C}(\mathrm{p}>0.05)$. DAP values during rewarming at Tbasal-RW, $34^{\circ} \mathrm{C}, 35^{\circ} \mathrm{C}, 36^{\circ} \mathrm{C}$ were lower as compared to the measurements during cooling period. $\boldsymbol{M A P}$ meaurements did not demonstrate any difference at Tbasal-C/ Tbasal-RW and $33^{\circ} \mathrm{C}(\mathrm{p}<0.05)$. MAP values during rewarming at $34^{\circ} \mathrm{C}, 35^{\circ} \mathrm{C}, 36^{\circ} \mathrm{C}$ were lower as compared to measurements during cooling period $(\mathrm{p}<0.05)$. $\boldsymbol{H R}$ and CVP measurement values at the same body temperature during rewarming and cooling period did nor demonstrate any difference ( $p>0.05)$. CO measurements were higher during the rewarming period $(p<0.05)$. CI measurements were higher during the rewarming period $(p<0.05)$. GEDI and ELWI measurements during rewarming and cooling periods did not demonstrate any difference at the same body temperatures $(p>0.05)$. SVRI measurements during rewarming and cooling periods at $33^{\circ} \mathrm{C}$ did nor demonstrate any difference $(p>0.05)$. SVRI values during rewarming period at $34^{\circ} \mathrm{C}, 35^{\circ} \mathrm{C}, 36^{\circ} \mathrm{C}$ and Tbasal-RW period were lower $(p<0.05)$.

C: Cooling, RW: Rewarning, BT: Body temperature, SAP: Systolic arterial pressure, DAP: Diastolic arterial pressure, MAP: Mean arterial pressure, HR: Heart rate, CVP: Central venous pressure, SVRI: Systemic vascular resistance index, CO: Cardiac output, CI: Cardiac index, GEDI: Global end-diastolic volume index, ELWI: Extravascular lung water index.

that patients kept at $33^{\circ} \mathrm{C}$ BT for about 24 hours experienced improved cardiac function during rewarming.

The rationale for applying $\mathrm{TH}$ in patients experiencing ROSC after CPR is to improve brain tolerance to ischemia. There are increasing reports of neurological disease-free survival and recovery in these situations $[17,18]$. Experimental studies demonstrated that hypothermic blood introduced to the coronary sinus during heart ischemia minimizes reperfusion damage and infarct area [19]. TH also protects contractility, prevents microvascular obstructions, and reduces left ventricular remodeling [20]. In addition, the reduced metabolic rate, decreased tissue apoptosis, and heat shock protein induction offer cellular protective effects [21]. The cardioprotective effects of $\mathrm{TH}$ are directly related to timing. Late induction or a slow cooling speed does not improve cardiac function [22,23]. The time from ROSC to $\mathrm{TH}$ induction was about $45 \mathrm{mi}$ nutes in our study. Although we selected $0.5^{\circ} \mathrm{C} / \mathrm{h}$ for cooling, new studies suggest that faster cooling $\left(>0.5^{\circ} \mathrm{C} / \mathrm{h}\right)$ to the targeted BT is associated with better cardioprotection $[24,25]$. According to Nagao et al., TH is more effective if begun during CPR prior to ROSC, and early cooling during $\mathrm{CA}$ is neuroprotective and myocardioprotective [26]. TH during CPR also increases resuscitation rates, 
improves cardiac and left ventricular function and decreases the myocardial infarct area $[27,28]$.

Schmidt-Schweda et al. showed that HR decreased whereas stroke volume (SV), CI and CO increased in cardiomyopathic patients receiving short-term cooling [29]. However, these improvements were lost during rewarming, and the authors interpreted $\mathrm{TH}$ application as having a positive inotropic effect [29]. In contrast, CO and $\mathrm{CI}$ in our study improved at the end of the cooling period and throughout rewarming, with the highest levels occurring at the end of the process. As per our protocol, dopamine and noradrenalin infusions were decreased or eliminated during rewarming. There were significant increases in $\mathrm{CO}$ and $\mathrm{CI}$, and a significant decrease in SVRI, but no significant change in GEDI or HR during the rewarming period compared with the cooling period. This might imply that there was an increased SV during the rewarming period resulting from either increased contractility or decreased afterload or both. Unfortunately, recent study findings could not distinguished between the two possibilities. Gibson et al. suggested that the $\mathrm{TH}$ adverse effects of bradycardia and hypotension actually benefit patients, similar to the effect of beta-blockers [30]. When Riaz et al. reported results of cooling patients to $32^{\circ} \mathrm{C}$ to $34^{\circ} \mathrm{C}$ for 24 hours following ventricular tachycardia or ventricular fibrillation, they emphasized the risk of QT interval prolongation, particularly in those who had received amiodarone [31].

Management of patients receiving CPR during $\mathrm{TH}$ is difficult $[8,9]$. The most frequent cause of complex hemodynamic instability is arterial hypotension, which is characterized by hypovolemia, reversible myocardial stunning and excessive vasodilation [32-36]. Pulmonary dysfunction is related to cardiogenic pulmonary edema caused by left ventricular dysfunction and non-cardiogenic edema caused by inflammatory, infective and physical damage [9]. We used $\mathrm{PiCCO}^{\circ}$ monitoring to improve patient care and track cardiac function during this difficult post-ROSC period. It has been reported that $\mathrm{PiCCO}^{\circ}$ monitoring with transpulmonary thermodilution may be compromised in patients receiving $\mathrm{TH}[37,38]$. For this reason, we compared cardiac function measurements at the same BTs during cooling and rewarming. However, there are inadequate prospective studies published regarding the reliability of $\mathrm{PiCCO}^{\circ}$ measurements at low BTs. Further prospective studies similar to ours are needed. Fluid and electrolyte balance during $\mathrm{TH}$ is an important challenge [39]. Cooling can cause peripheral vasoconstriction, reduce vascular volume and CVP, and the patient seems relatively hypovolemic [40]. In our study, we detected no significant change in CVP and HR, but we did detect higher $\mathrm{CO}$ and $\mathrm{CI}$ values. During these therapeutic cooling and rewarming periods, patient fluid status must be monitored closely to maintain volume balance, and a vasopressor added when necessary to maintain adequate blood pressure.

Post-resuscitation hemodynamic instability is characterized by a low $\mathrm{CI}$ and normal or low filling pressures [33]. The CI rapidly increases 24 hour after CA, independent of filling pressures and vasoactive agents [41]. Recovery of this myocardial dysfunction is most often obtained within 24-48 hours and this condition might have played a role in our findings [33]. Full recovery with discontinuation of inotropic support has usually occurred by 72 hours after ROSC [41]. In contrast, TH has been shown to produce negative effects as well as cardioprotective effects. Espinoza et al. showed that $\mathrm{TH}$ in pigs decreased SV, ejection fraction and strain in hearts paced at $33^{\circ} \mathrm{C}$, and concluded that $\mathrm{TH}$ may lead to systolic and diastolic dysfunction [42]. When Bassin et al. induced hypothermia in sheep using venous extracorporeal circulation, they observed increased heterogeneity in hypothermic depolarization and repolarization during cardiac rhythm tracking by 12-derivation ECG, thus providing strong evidence that hypothermia to $34^{\circ} \mathrm{C}$ produced adverse effects [43].

Several limitations of the current study deserve mention. We did not select a control group so we do not know how cardiac functions would have differed from patients who did not receive $\mathrm{TH}$. We were also unable to study patients undergoing angioplasty following $\mathrm{CA}$ as a result of myocardial infarction or patients with known underlying cardiac disease. Once TH was complete, we did not collect $\mathrm{PiCCO}^{\circ}$ measurements. Thus, we could not determine whether the beneficial cardiac function changes persisted over time.

\section{Conclusions}

This study found that $\mathrm{CO}$ and $\mathrm{CI}$ increased together during rewarming following $\mathrm{TH}$. The lack of difference in $\mathrm{HR}$ measurements indicate that $\mathrm{CO}$ and $\mathrm{CI}$ increased by increases in TH and SV. To our knowledge, this is the first study comparing cardiac function at the same BTs during cooling and rewarming. In patients experiencing ROSC following CPR, TH may improve cardiac function. Further studies are needed to confirm these results and the relationship between $\mathrm{TH}$ and post-resuscitation myocardial function in patients with different neurological status.

\section{Abbreviations}

MH: Mild hypothermia; BT: Body temperature; CPR: Cardiopulmonary resuscitation; TH: Therapeutic hypothermia; ROSC: Return of spontaneous circulation; SAP: Systolic artery pressure; DAP: Diastolic artery pressure; MAP: Mean arterial pressure; CO: Cardiac output; Cl: Cardiac index; GEDI: Global end-diastolic volume index; ELWI: Extravascular lung water index; SVRI: Systemic vascular resistance index; CA: Cardiac arrest; ERC: European Resuscitation Council; HR: Heart rate; CVP: Central venous pressure; SV: Stroke volume.

Competing interests

The authors declare they have no competing interests. 


\section{Authors' contributions}

SD conceived and designed the study, conducted the literature review, wrote and critically reviewed the paper. KE conceived and designed the study, analyzed and interpreted the data, conducted the literature review, wrote and critically reviewed the paper. MSS supervised the study, conducted the literature review, wrote and critically reviewed the paper. MTA supervised the study, analyzed and interpreted the data. AA supervised the study, analyzed and interpreted the data, and critically reviewed the paper. NK provided funding and materials, and collected and processed the data. AF provided funding and materials, and collected and processed the data. AO provided funding and materials. All authors read and approved the final manuscript.

\section{Acknowledgements}

We thank to Jack Tuncay (Istanbul, Turkey) and Squirrel Scribe, LLC (NewYork, USA) for professional language editing.

Received: 24 February 2014 Accepted: 11 September 2014 Published: 18 September 2014

\section{References}

1. Bernard SA, Gray TW, Buist MD, Jones BM, Silvester W, Gutteridge G, Smith K: Treatment of comatose survivors of out-of-hospital cardiac arrest with induced hypothermia. N Engl J Med 2002, 346:557-569.

2. The Hypothermia after Cardiac Arrest Study Group: Mild therapeutic hypothermia to improve the neurologic outcome after cardiac arrest. N Engl J Med 2002, 346:549-556.

3. Gardner G, MacDonald S: Caring for patients receiving therapeutic hypothermia post cardiac arrest in the intensive care unit. Can J Cardiovasc Nurs 2013, 23:15-17.

4. Chien GL, Wolff RA, van Winkle DM: Normothermic range temperature affects myocardial infarct size. Cardiovasc Res 1994, 28:1014-1017.

5. Tissier R, Chenoune M, Ghaleh B, Cohen MV, Downey JM, Berdeaux A: The small chill: mild hypothermia for cardioprotection. Cardiovasc Res 2010, 88:406-414.

6. Negovsky VA: Postresuscitation disease. Crit Care Med 1988, 16:942-946

7. Morrison L, Deakin CD, Morley PT, Callaway CW, Kerber RE, Kronick SL, Lavonas EJ, Link MS, Neumar RW, Otto CW, Parr M, Shuster M, Sunde K, Peberdy MA, Tang W, Hoek TL, Böttiger BW, Drajer S, Lim SH, Nolan JP, Advanced Life Support Chapter Collaborators: International consensus on cardiopulmonary resusitation and emergency cardiovascular care science with treatment recommendations. Circulation 2010, 122:345-421.

8. Neumar RW, Nolan JP, Adrie C, Aibiki M, Berg RA, Böttiger BW, Callaway C, Clark RS, Geocadin RG, Jauch EC, Kern KB, Laurent I, Longstreth WT Jr, Merchant RM, Morley P, Morrison LJ, Nadkarni V, Peberdy MA, Rivers EP, Rodriguez-Nunez A, Sellke FW, Spaulding C, Sunde K, Vanden HT: Post-cardiac arrest syndrome: epidemiology, pathophysiology, treatment, and prognostication: a consensus statement from the international Liaison Committee. Circulation 2008, 118:2452-2483.

9. Peberdy MA, Callaway CW, Neumar RW, Geocadin RG, Zimmerman JL, Donnino M, Gabrielli A, Silvers SM, Zaritsky AL, Merchant R, Vanden Hoek TL, Kronick SL: American Heart Association guidelines for cardiopulmonary resuscitation and emergency cardiovascular care. Circulation 2010, 122:768-786.

10. Binks AC, Murphy RE, Prout RE, Bhayani S, Griffiths CA, Mitchell T, Padkin A Nolan JP: Therapeutic hypothermia after cardiac arrest implementation in UK intensive care units. Anaesthesia 2010, 65:260-265.

11. Laver SR, Padkin A, Atalla A, Nolan JP: Therapeutic hypothermia after cardiac arrest: a survey of practice in intensive care units in the United Kingdom. Anaesthesia 2006, 61:873-877.

12. Hazinski MF, Nolan JP, Billi JE, Böttiger BW, Bossaert L, de Caen AR, Deakin CD, Drajer S, Eigel B, Hickey RW, Jacobs I, Kleinman ME, Kloeck W, Koster RW, Lim SH, Mancini ME, Montgomery WH, Morley PT, Morrison $\sqcup$, Nadkarni VM, O'Connor RE, Okada K, Perlman JM, Sayre MR, Shuster M, Soar J, Sunde K, Travers AH, Wyllie J, Zideman D: International consensus on cardiopulmonary resuscitation and emergency cardiovascular care science with treatment recommendations. Circulation 2010, 122:250-275.

13. Field JM, Hazinski MF, Sayre MR, Chameides L, Schexnayder SM, Hemphill R, Samson RA, Kattwinkel J, Berg RA, Bhanji F, Cave DM, Jauch EC, Kudenchuk PJ, Neumar RW, Peberdy MA, Perlman JM, Sinz E, Travers AH, Berg MD, Billi JE, Eigel B, Hickey RW, Kleinman ME, Link MS, Morrison LJ, O'Connor RE,
Shuster M, Callaway CW, Cucchiara B, Ferguson JD, et al: American Heart Association guidelines for cardiopulmonary resuscitation and emergency cardiovascular care. Circulation 2010, 122:640-656.

14. Hori S: New evidences in the 2010 international consensus on cardiopulmonary resuscitation and emergency cardiovascular care with treatment recommendations. Nihon Rinsho 2011, 69(4):605-611.

15. Nolan JP, Soar J, Zideman DA, Biarent D, Bossaert LL, Deakin C, Koster RW, Wyllie J, Böttiger B: European Resuscitation Council Guidelines for Resuscitation 2010. Resuscitation 2010, 81:1219-1276.

16. Ramsay MA, Savage TM, Simpson BR, Goodwin R: Controlled sedation with alphaxalone-alphadolone. Br Med J 1974, 2:656-659.

17. Hay AW, Swann DG, Bell K, Walsh TS, Cook B: Therapeutic hypothermia in comatose patients after out-of hospital cardiac arrest. Anaesthesia 2008, 34:1865-1873.

18. Nielsen N, Hovdenes J, Nilsson F, Rubertsson S, Stammet P, Sunde K, Valsson $F$, Wanscher $M$, Friberg $H$ : Outcome, timing and advers events in therapeutic hypothermia after-out-of-hospital cardiac arrest. Acta Anaesthesiol Scand 2009, 53:926-934.

19. Haendchen RV, Corday E, Meerbaum S, Povzhitkov M, Rit J, Fishbein MC: Prevention of ischemic injury and early reperfusion derangements by hypothermic retroperfusion. Am Coll Cardiol 1983, 1:1067-1080.

20. Hale SL, Kloner RA: Mild hypothermia as a cardioprotective approach for acute myocardial infarction: laboratory to clinical application. J Cardiovasc Pharmacol Ther 2011, 16:131-139.

21. Ma H, Sinha B, Pandya RS, Lin N, Popp AJ, Li J, Yao J, Wang X: Therapeutic hypothermia as a neuroprotective strategy in neonatal hypoxic-ischemic brain injury and traumatic brain injury. Curr Mol Med 2012, 12:1282-1296.

22. Deakin CD, Nolan JP, Soar J, Sunde K, Koster RW, Smith GB, Perkins GD: European Resuscitation Council Guidelines for Resuscitation 2010: Adult advanced life support. Resuscitation 2010, 81:1305-1352.

23. van der Wal G, Brinkman S, Bisschops LL, Hoedemaekers CW, van der Hoeven JG, de Lange DW, de Keizer NF, Pickkers P: Influence of mild therapeutic hypothermia after cardiac arrest on hospital mortality. Crit Care Med 2011, 39:84-88

24. Sunde K, Pytte M, Jacobsen D, Mangschau A, Jensen LP, Smedsrud C, Draegni T, Steen PA: Implementation of a standardised treatment protocol for post resuscitation care after out-of-hospital cardiac arrest. Resuscitation 2007, 73:29-39.

25. Nunnally ME, Jaeschke R, Bellingan GJ, Lacroix J, Mourvillier B, Rodriguez-Vega GM, Rubertsson S, Vassilakopoulos T, Weinert C, Zanotti-Cavazzoni S, Buchman TG: Targeted temperature management in critical care: a report and recommendations from five five professional societies. Crit Care Med 2011, 16:1113-1125.

26. Nagao K: Therapeutic hypothermia following resuscitation. Curr Opin Crit Care 2012, 18(3):239-245.

27. Abella BS, Zhao D, Alvarado J, Hamann K, Vanden Hoek TL, Becker LB: Intra-arrest cooling improves outcomes in a murine cardiac arrest model. Circulation 2004, 16:2786-2791.

28. Scolletta S, Taccone FS, Nordberg P, Donadello K, Vincent JL, Castren M: Intra-arrest hypothermia during cardiac arrest: a systematic review. Crit Care 2012, 16(2):R41.

29. Schmidt-Schweda S, Ohler A, Post H, Pieske B: Moderate hypothermia for severe cardiogenic shock. Resuscitation 2013, 84:319-325.

30. Gibson A, Andrews PJ: Therapeutic hypothermia, still "too cool to be true?". F1000Prime Rep 2013, 5:26.

31. Riaz A, Hieb H, Foley B, Mulvihill N, Crean P, Murphy RT, Daly C, Boyle N: Safety of therapeutic hypothermia in post VF/NT cardiac arrest patients. Ir Med J 2013, 106(2):55-56

32. Kelly FE, Nolan JP: The effect of mild induced hypothermia on the myocardium: a systematic review. Anaesthesia 2010, 65:505-515.

33. Laurent I, Monchi M, Chiche JD, Joly LM, Spaulding C, Bourgeois B, Cariou A, Rozenberg A, Carli P, Weber S, Dhainaut JF: Reversibl myocardial dysfunction in survivors of out-of-hospital cardiac arrest. J Am Coll Cardiol 2002, 40:2110-2116

34. Chang WT, Ma MH, Chien KL, Huang CH, Tsai MS, Shih FY, Yuan A, Tsai KC, Lin FY, Lee YT, Chen WJ: Postresuscitation myocardial dsyfunction: correlated factors and prognostic implications. Intensive Care Med 2007, 33:88-95.

35. Adrie C, Adib-Conquy M, Laurent I, Monchi M, Vinsonneau C, Fitting C, Fraisse F, Dinh-Xuan AT, Carli P, Spaulding C, Dhainaut JF, Cavaillon JM: Successful cardiopulmonary resuscitation after cardiac arrest as a sepsis like syndrome. Circulation 2002, 106:562-568. 
36. Adrie C, Laurent I, Monchi M, Cariou A, Dhainaou JF, Spaulding C: Postresuscitation disease after cardiac arrest: sepsis like syndrome? Curr Opin Crit Care 2004, 10:208-212.

37. Monnet X, Persichini R, Ktari M, Jozwiak M, Richard C, Teboul JL: Precision of the transpulmonary thermodilution measurements. Crit Care 2011, 15:204

38. Gondos T, Marjanek Z, Kisvarga Z, Halasz G: Precision of transpulmonary thermodilution: how many measurements are necessary? Eur $J$ Anaesthesiol 2009, 26:508-512.

39. Prempunpong C, Efanov I, Santanna G: The effect of implementation of therapeutic hypothermia on fluid balance and incidence of hyponatremia in neonates with moderate or severe hypoxic-ischaemic encephalopathy. Acta Paediatr 2013, 102(11):e507-e513.

40. Davies MG, Hopkin MA, Brockbank KG, Hagen PO: Hypothermia and rewarming after hypothermic exposure alter venous relaxation. Vasc Med 1996, 1:103-107.

41. Kern KB, Hilwig RW, Rhee KH, Berg RA: Myocardial dysfunction of resuscitation from cardiac arrest: an example of global myocardial stunning. J Am Coll Cardiol 1996, 28:232-240.

42. Espinoza A, Kerans V, Opdahl A, Skulstad H, Halvorsen PS, Bugge JF, Fosse E, Edvardsen T: Effects of therapeutic hypothermia on left ventricular function assessed by ultrasound imaging. J Am Soc Echocardiogr 2013, 26(11):1353-1363.

43. Bassin L, Yong AC, Kilpatrick D, Hunyor SN: Arrhythmogenicity of hypothermia- a large animal model of hypothermia. Heart Lung Circ 2014, 23(1):82-87.

doi:10.1186/1471-2253-14-78

Cite this article as: Demirgan et al:: Cardiac condition during cooling and rewarming periods of therapeutic hypothermia after cardiopulmonary resuscitation. BMC Anesthesiology 2014 14:78.

\section{Submit your next manuscript to BioMed Central and take full advantage of:}

- Convenient online submission

- Thorough peer review

- No space constraints or color figure charges

- Immediate publication on acceptance

- Inclusion in PubMed, CAS, Scopus and Google Scholar

- Research which is freely available for redistribution 